\title{
Revisiting Community Bidayuh Empowerment Using Abductive Research Strategy
}

\author{
N. Lyndon ${ }^{1}$, A. C. Er ${ }^{1}$, S. Selvadurai ${ }^{1}$, M. S. Sarmila ${ }^{1}$, M. J. Fuad ${ }^{1}$, R. Zaimah ${ }^{1}$, Azimah A. M. ${ }^{1}$, Suhana S. ${ }^{1}$, A. \\ Mohd Nor Shahizan ${ }^{2}$, Ali Salman² \& Rose Amnah Abd Rauf ${ }^{3}$ \\ ${ }^{1}$ School of Social, Development and Environmental Studies, Faculty of Social Sciences and Humanities, \\ Universiti Kebangsaan Malaysia, Bangi, Malaysia \\ ${ }^{2}$ School of Media and Communication Studies, Universiti Kebangsaan Malaysia, Bangi, Malaysia \\ ${ }^{3}$ Faculty of Education, Universiti Malaya (UM), Malaysia \\ Correspondence: N. Lyndon, School of Social, Development and Environmental Studies, Faculty of Social \\ Sciences and Humanities, Universiti Kebangsaan Malaysia, Bangi, Malaysia. Tel: 60-3-8921-4212. E-mail: \\ novellyndon@gmail.com
}

Received: December 19, $2012 \quad$ Accepted: March 29, $2013 \quad$ Online Published: April 25, 2013
$\begin{aligned} & \text { doi:10.5539/ass.v9n8p64 } \\ & \text { URL: http://dx.doi.org/10.5539/ass.v9n8p64 }\end{aligned}$

This research was supported by Centre for Research and Instrument Management, under the research university grant, Universiti Kebangsaan Malaysia: UKM-GGPM-PLW-018-2011

\begin{abstract}
Previous studies shows that the failure of community development in Malaysia always related with two aspects such as the emphasis on top-down approach which is the centralization of power without the active participation of community members and also a limited understanding of the needs and aspirations of the local people. Therefore the main objective of this study is to understand the meaning of empowerment from the world-view of Bidayuh community itself. This study using abductive research strategy and a phenomenology research paradigm which is based on idealist ontology and constructionist epistemology. This paradigm focuses on the lived experience of the Bidayuh Bukar community which are shaped by their own value and daily life experience. Data was gathered through in-depth interviews conducted with 50 informants. The Bidayuh understanding of empowerment was analysed from themes derived from the knowledge, experience, interpretation, action and the reaction of the Bidayuh Bukar community world view. The findings show that the Bidayuh understanding of empowerment is a process in which power is developed, promoted, obtained, shared, simplified or adapted by individual or groups in social interaction that would allow them the ability to use internal capability themselves to do something, to take effect and make a difference in the community as a product that has been strengthened. In short, it refers to a process in which a person or a group are at a point where they are able to use the skills, ability and capacity themselves in understanding, interpreting problems and then define the requirements and translate these requirements to the process definition action through participation in the organization itself.
\end{abstract}

Keywords: community development, poverty, empowerment, Bidayuh community

\section{Introduction}

Studies carried out by Shamsul (1977), Herbert-Cheshire (2000), Lavers (2008), and Lyndon et al. (2012) shows that community development is a planned intervention that gives communities opportunities for much control over the conditions that affect their lives. Nevertheless, this does not adequately provide solutions to the the problems faced by the local community (Lavers, 2008; Lyndon et al., 2012). Past studies have unmistakably shown that the inability and ineptness of community development program to improve the economic conditions and quality of life of indigenous communities in Malaysia and Sarawak are often connected with planners refusal to recognize the needs and the aspirations of the community from their emic world view (Asnarulkhadi, 1996; Madeline, 2004; Jones, 2003; Xu \& Chow, 2006, Novel et al., 2011). Besides that, the implementation of the development program characteristically highlights two features: firstly, at the macro structural level, the ideas, concepts and the understanding of planners or agencies are often shaped by the scientific etic world view, and secondly, there is a inclination to adopt Rostow's theories of modernization ignoring the importance of the emic 
world view, social system, and culture of the community itself (Denison, 1996; Chamhuri, 1985; Morris et al, 1999; Sharina \& Hood, 2007). This condition has led to inadeaquate and abandonment of understanding and knowledge about the needs and aspiration of the community.

On top of that, the needs and wants are two different concepts with divergent standpoints. The needs refer to the specific categories of the universal etic goals that are relevant and necessary to all people in order to survive. On the other hand, the wants or desire originates from something that is favoured by the individual and cultural context (Lavers, 2008). Both concepts offer different view, in terms of approach, and in terms of understanding of the notion of poverty (Yapa, 1996; McGregor et al, 2009; Chambers, 1994). Planners are more prone to utilize symbolic approach instead of integrative and holistic approach. This is because they have limited time to examine the process and the direction of change which are influential in shaping program outcomes (Songan, 1993; Tosun, 2000; Haris, 2004; Colin, 2004). On the other hand, at the micro-level, the recipients of the development programme utilized approach based on personal experiences, needs and aspirations that are formed by their emic world view. Nevertheless, they have similar goals to address in terms of eradicating poverty and improving their quality of life (Ngidang \& Abdul, 1999; Berke, 2002; Robertson, 1984). These goals and aspirations has been the motivating force to undertake this research. Other researchers have indicated that the failure of development programs was also related to feudalistic tendencies in developing world such as the importance given to top-down approach, and as a consequent leading to greater concentration of power amongst the local elites, resulting poor participation from the community members (Ong, 2007; Healey, 2003; Cohen \& Uphoff, 1980), a partial understanding of needs, capacities and desires of the beneficiary of development programs (Lyndon et al., 2012; Collaborative Learning Project, 2011; Sen, 1999), a weak administrative structure (Dauvergne, 1997; Van, 2001), a shallow and narrow understanding of the conceptual and measurement of poverty (Thorbecke, 2004; Brady, 2003; Wan, 1998), marginalization of local knowledge, beliefs, values and social systems of recipients of development programs (Gadgil et al., 2003; Chambers, 1994; Hall et al., 2000) and finally, features of participation and empowering people (Ong, 2007; Zakus \& Lysack,1998; Lyndon et al., 2011; Colin, 2004). This is the theoretical gap that we would like to investigate in this study. Therefore, the objective of this paper is to determine the Bidayuh understanding of empowerment in community development from their own world view.

\section{Methodology}

\subsection{Description of Study Area}

Serian is under the Samarahan Division and administered by a resident after officially designated as Samarahan Division on January 1, 1987 (Sarawak, 2010). Each province is administered by the District Officer. Meanwhile, sub-district was administered by an Administrative Officer (Samarahan Resident Office, 2009; Administration, Department of the Chief Minister, 2010). Serian actually was one of the four districts in Samarahan Division, Sarawak (Sarawak, 2010) (see figure 1). Historically inception, Serian District was established in 1901 and known as Sadong District. In February 1955, it was known as Serian (Upper Sadong) after Simunjan (Lower Sadong) separated and each upgraded to a full district. Serian district covers an area of about 2.106 square kilometers and is located about 64 kilometers south of Kuching City or an hour's drive from Kuching and have a small district, sub-district of the Tebedu the Main Entrance (International Border Crossing) for Malaysia / Indonesia (in Sarawak) (Sarawak, 2010).

Tebedu Sub District is located 43 kilometers from the town of Serian. Serian generally bordered by the Kuching Division in the northern region, Simunjan District in the east and West Kalimantan, Indonesia in the south. Serian District has a major city and small town into seven business center district population (Sarawak, 2007). The main town is known as the City of Serian and is among one of the selected areas of Sarawak in Healthy Cities Program since 2001. Local residents were named this city as urban transit (Sarawak, 2010). This is because its route is Pan Borneo highway and Pearl City, Tebedu. The users often stop on the route either to take a break, buy handicrafts and stomach as food or take on supplies for the next journey. Meanwhile, the small town in Serian District consists of five main towns namely Balai Ringin, Tarat, Tebakang, Mongkos and Tebedu. Most of these small towns have at least 20 shop houses. Tebedu town was located 3 kilometers from Tebedu Immigration Complex. It was built in 1993 and has 68 shop houses (Sarawak, 2010). In fact, about 90 percent of the villages in Serian District can be contacted through the main road as a whole is rocky or paved (Sarawak, 2007). However, there are also a few villages which are still connected by red soil road or river gravel and communication especially for villages' tucked away location in the interior as Mongkos, Kedup and Tebedu. The village is located near the border between Malaysia and Indonesia. Most of the villages in this area are limited in terms of accessibility to information technology, transportation or communication networks, the use of clean piped water and electricity. 
In general, Bidayuh ethnic can be divided into four fractions based on four main dialects spoken of being Salako-Lara, Bau-Jagoi, Biatah and Bukar-Sadong (Minos, 2000). Salako-Lara dialect commonly spoken by the Bidayuh community in Lundu District. However Bau-Jagoi dialect and Biatah living in some areas of Bau, Padawan, Siburan and Penrisen. Next Bukar-Sadong dialect can be found in Serian District (Sarawak, 2010). According to the 2010 census, the total population of people in Serian is estimated around 95,433. Out of this, are Bidayuh $(49,117$ or $61.4 \%)$, followed by Iban (12,147 or $15.2 \%)$ Chinese $(10,204$ or $12.8 \%)$ and Malay $(9,519$ or $11.9 \%$ ) (Sarawak, 2010). There are about 222 villages of Bidayuh community in District of Serian. Only ten villages were the Bidayuh areas, namely Kg Rayang, Kg Ampungan, Kg Riih Mawang, Kg Pichin, Kg Tebakang Dayak, Kg Tangga Mawang, Kg Jenan, Kg Tebedu Mawang, Kg Mujat and Kg Mentu Pondok (Sarawak, 2010). The study area for this research covers the two villages, which are Kpg Tebedu Mawang and $\mathrm{Kg}$ Mujat at Mongkos and Tebedu zones where the poverty program was carried out (see figure 1 below).

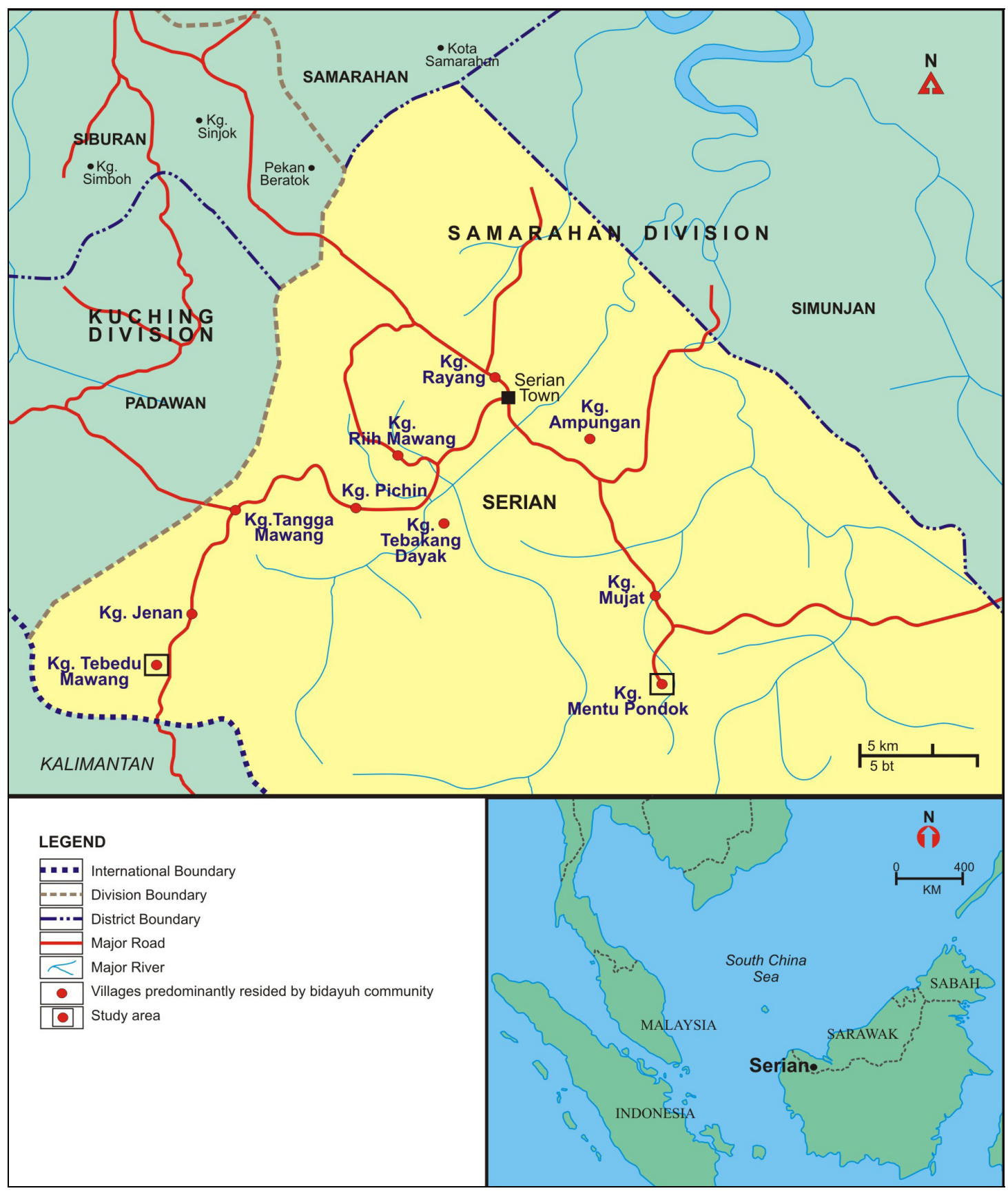

Figure 1. The study area 


\subsection{Research Design}

This research used the phenomenology paradigm that explores the "human experience and the way in which things are perceived as they appear to consciousness" (Langdridge, 2007:10). In this respect it entails the construction of theories that are grounded in everyday activities, in the language and meaning of social actors (Lyndon et al., 2012; Blaikie, 2000). Phenomenology is concerned with the study of experience from the perspective of the individual, 'bracketing' taken-for-granted assumptions and usual ways of perceiving. It is based on idealist ontology and the epistemology of constructionism. To describe and understand social life of rural communities' motives and understanding, the abductive approach as proposed by Blaikie, 2000; Schutz, 1976 and Giddens, 1982 were used. This is because the world view of Bidayuh community includes the properties of social life, including the world view of community members in common sense (common-sense world), the world of everyday life, everyday world of work and ordinary reality (common reality).

\subsection{Data Collection}

In this study, data were collected using in-depth interviews over a period of four months. In-depth interviews in this study involves a conversation between two parties that between researchers and informants with a specific purpose, namely to understand the meaning of empowerment from the world-view of the Bidayuh community. The interviews between researchers and informants in this study are focusing on their daily life and their understanding about life using their own words. Most of the interview conducted in this study took about two hours to three hours using Bidayuh language and later were translated to Malay language. In this study, not all the interviews are recorded with audio or voice recorder. This is due to some of the informants mentioned that there are uncomfortable with the audio recording. To overcome this problem, the researchers then use the notebook to make notes on any information obtained from the informants. This note will then be copied (transcribed) as soon as possible upon completion of the interviews with the respondents. This action must be taken to ensure that researchers do not lose any important information. Therefore, researchers have been unable to make many interviews with respondents in one day. This situation has led researchers to take a relatively long time to complete his fieldwork. Apart from face to face interviews with the informants, the researchers are taking advantage and opportunity to participate in weekly meetings conducted by the villages Development Committee in a few villages in Serian District where the poverty program are conducted and a monthly seminar which are organized by the Serian District Office. Informal group discussions with the Bidayuh community also conducted with the aim to increase the finding of study. In this study, after a sequence of 30 interviews with informants, the data reached saturation after 50 interviews. Data saturation refers to the point where the information gathered from the informants becomes redundant and the patterns are seen repeatedly (Blaikie, 2000; Minichiello et al., 1995; Bogdan \& Biklen, 1992; Glaser \& Strauss, 1974)

\subsection{Data Analysis}

All interviews were transcribed and formatted for inclusion in the database. The Nvivo program were used to create categories and to indexing the data. Nvivo is software that created or specially designed to storage and to manage the overall analysis of qualitative data. Since the data is in the form of a transcript, the methods used are more geared to create categories, sorting data to detect patterns and to elaborate the patterns. There are seven series of activities carried out by the researchers during the process of data analysis conducted. The sequence of data analysis activities are as follows: i) data was transcribed from recorded interview of each informant, written in native language of the researched participants; ii) the tape interviews were reviewed at least twice to ensure that there are no mistake been made or left out; iii) upon completion of the transcription process, each transcript or text will then be reviewed or taken into consideration a few times and restructured to reflect a brief description of the meaning of empowerment of the Bidayuh community. Further, this will drive the data cleaning process includes making some appropriate correction and removal of some of the data that is excessive or repeated; iv) data are then stored in a file with a different name; v) the transcript then send to peer review to check the accuracy of the translation and meaning. The themes in the language native on empowerment are still retained; and lastly vi) involves managing the data by constructing categories into a matrix table, tabulating the findings into a more organized fashion; (vii) using the themes produced from constant comparative analysis; and (viii) particular quotes were tabulated according to the line numbers that appear in the script.

\section{Results and Discussion}

\subsection{Bidayuh Understanding of Empowerment in Poverty Program}

Majority of the informants felt that the meaning of empowerment refers to the individual feelings to increase its power; a capacity to influence the powers which affect a person's life space for the benefit of themselves without changing the social structure and also including to what extent the individual or community members have 
allowed themselves to be empowered to make an impact and bring social change in their life. At the same time, they also have power to control or influence the decision that were taken particularly in the planning and implementation stages. For example, R1 in fact states that the major component of empowerment comprises the ability of the individual to gain more control in determining their life and also an ability to generate ideas or ideas that can be shared with the community. Other informants like R2, R3, R4, R5, R6 and R8 also argue that priority should be given to build and strengthen the individual ability to gain control high on life, the ability to understand the social and political reality, have the knowledge and skill in the face of problems and stress and nurturing resources and strategies that facilitate collective goals. Meanwhile, R9 in his statement noted "empowerment as are developmental process that begins with the individual and then cumulatively growth toward the great social change. This is because the concept of empowerment is a process in which power is developed, promoted, obtained, shared, simplified or adapted by individual or groups in social interaction that would allow them the ability to use their own internal capability to do something, to take effect and make a difference in the community particularly in their quality of life. Most of the informants also agree that the empowerment in poverty program refers to a process of increasing the capacity of individuals or groups to make choices and to transform those choices into desired actions and outcomes. In addition, it also involves a multi-dimensional social process that helps local people gain control over their own lives. In other words, it is a process that fosters power in local people for use in their own lives, their communities, and in their society by acting on issues that they define as important. Therefore, majority of the informant in this study also revealed that empowerment is multi-dimensional, social, and a process. This is because it is occurs within sociological, psychological, economic, and other dimensions such as political and social institution. Empowerment also occurs at various levels, such as individual, group, and community. This argument are related with previous studies which shows that the possibility of empowerment depends on two things. First, empowerment requires that power can change (Itzhaky \& York, 2000; Denison, 1996; Lyndon, et al., 2012). If power cannot change, if it is inherent in positions or people, then empowerment is not possible, nor is empowerment conceivable in any meaningful way. In other words, if power can change, then empowerment is possible (McGregor et al. 2009; Colin, 2004; Thorbecke, 2004). Second, the concept of empowerment depends upon the idea that power can expand (Lyndon, 2012; Hall et al., 2004).

There are also some informants who rose about aspect of self empowerment or individual power which an individual has the strength and ability to make their own decisions without relying on the views and opinions of others. According to them, self-empowerment refers to social relationship that form the quality of social interaction in the community which then allows community members in the community to study together with each other. At the same time empowerment often addresses members of groups that social discrimination processes have excluded from decision-making processes through discrimination based on disability. For Example, R13, R14, R15, believes that self- empowerment or individual power should cover aspects such as authority, ability to influence organization and to employ that strength when engaging with other people, institutions or society. This is in line with what previous studies revealed before about empowerment. The concept of empowerment is not giving people power; people already have plenty of power, in the wealth of their knowledge and motivation, to do their jobs magnificently. It encourages people to gain the skills and knowledge that will allow them to overcome obstacles in life or work environment and ultimately, help them develop within themselves or in the society (Lyndon et al., 2012; Hoque \& Itohara, 2009). Thus, R16, R17, R18 and R20 suggested that issues that may hinder the success of self-empowerment relatively associate with factors such as an organizational culture that does not support empowering process, high organizational structure, the determination of the scope of work and responsibilities, uncertainty authorization levels, inadequate remuneration and the issue of knowledge.

\section{Conclusion}

Based on the feedback given by the informants, it is clear that the meaning of empowerment is a very important aspect in the life of the Bidayuh community. The concept is meant by their power over to the concept of individual power. This is because the elements that they brought more focus on aspects such as individual ability, emotional control, knowledge of the community, the efficiency in decision-making and problem-solving, more positive attitude towards life, greater confidence in solving problems, changes in attitudes and skills when interacting with others, appreciate the help of others and so on. Hence, the meaning of empowerment presented by the individual as a whole can be divided into three main components consisting of individual internal power, external power and finally empowering individual's additional individuals. Among the features found in the internal power such as more on a positive attitude, level of confidence and ability to accept any failure. Meanwhile, the features found in the external power individuals are more on social skills such as having the 
ability to help others, learn how to accept the help of others, have good relationships with others and more thoughtful. Finally, additional power is referring to the system of leadership in the community and the relationships within the community members and family.

\section{Acknowledgments}

This research was supported by Centre for Research and Instrument Management, under the research university grant, Universiti Kebangsaan Malaysia. The researcher would like to thank University Kebangsaan Malaysia for the provision of the Research University Grant UKM-GGPM-PLW-018-2011 which enables smooth implementation of this research.

\section{References}

Asnarulkhadi, A. S. (1996). People's participation in community development and community work activities. Unpublished Doctoral Thesis, University of Nottingham. United Kingdom.

Berke, P. R. (2002). Does Sustainable Development Offer a New Direction for Planning? Challenges for theTwenty-First Century. Journal of Planning Literature, 17(1), 21-36. Retrieved from http://arroyofilms.com/ftpuser/2nd\%20wknd/Berke.pdf http://dx.doi.org/10.1177/088122017001002

Blaikie, N. (2000). Designing Social Research: The Logic of Anticipation. Cambridge: Polity Press.

Bogdan, R. C., \& Biklen, S. K. (1992). Qualitative Research in Education: An Introduction to Theory and Methods. Needham Heights, MA: Allyn and Bacon.

Chambers, R. (1994). The origins and practice of participatory rural appraisal. World Development, 22(7), 953-969. http://dx.doi.org/10.1016/0305-750X(94)90141-4

Chamhuri, S. (1985). Persistent poverty among paddy farmers: impact and implication of the Paddy Subsidy Scheme. Paper presented at Seminar on Problems and Prospects on rural Malaysia, Consumer Association of Penang, Penang, November.

Cohen, J. M., \& Uphoff, N. T. (1980). Particpation's place in rural development: Seeking clarity through specificity. World Development, 8(3), 213-235. http://dx.doi.org/10.1016/0305-750X(80)90011-X

Colin, N. (2004). The Orang asli: First on the Land, Last in the Plan. Journal of Malaysia Studies, 21(2), 315-330.

Collaborative Learning Project. (2011). The Listening Project Issue Paper: Whose Development? Aid Recipient $\begin{array}{llll}\text { Perspectives on Ownership. } & \text { Retrieved }\end{array}$

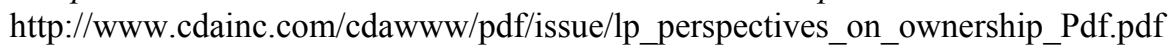

Dauvergne, P. (1997). Weak states and the environment in Indonesia and the Solomon Islands. Resource Management in Asia-PacificWorking Paper No. 10. The Australian National University: Canberra. Retrieved from http://www.crawford.anu.edu.au/rmap/pdf/Wpapers/rmap_wp10.rtf

Denison, D. R. (1996). What is the difference between organizational culture and organizational climate? A native's point of view on a decade of paradigm wars. Academy of management Review, 21(3), 619-654.

Gadgil, M., Olsson, P., Berkes, F., \& Folke, C. (2003). Exploring the role of local ecological knowledge in ecosystem management: three case studies. In F. Berkes, J. Colding, \& C. Folke (Eds.), Navigating Social-ecological systems building resilience for complexity and change. Cambridge: Cambridge University Press.

Giddens, A., (1982). Profiles and Critiques in Social Theory. London: Macmillan.

Glaser, B. G., \& Strauss, A. L. (1974). The Discovery of Grounded Theory: Strategies for Qualitative Research. Chicago: Aldine Publishing Company.

Hall, B. L., Sefa Dei, G. J., \& Dorothy Goldin Rosenberg, D. G. (2000). Indigenous Knowledges in Global Contexts: Multiple Readings of Our World. Toronto: University of Toronto Press.

Haris, A. W. (2004). Penglibatan masyarakat tempatan dalam projek pembangunan komuniti. In S. Dalam Dani (Ed.), Pembangunan Komuniti: Dasar, Konsep, Strategi dan Isu Di Malaysia (pp. 41-62). Sintok: Penerbit Universiti Utara Malaysia.

Healey, P. (2003). Collaborative planning in perspective. Planning Theory, 2(2), 101-123. http://dx.doi.org/10.1177/14730952030022002

Herbert-Cheshire, L. (2000). Contemporary strategies for rural community development in Australia: a 
governmentality perspective. Journal of Rural Studies, 16(2), 203-215. http://dx.doi.org/10.1016/S0743-0167(99)00054-6

Horowitz, M. (1998). Development and the Anthropological Encounter: A Reflective Underview. Development Anthropologist, 16(2), 44-50.

Jones, P. S. (2003). Urban regeneration's poisoned chalice: Is there an impasse in community participation-based policy? Urban Studies, 40(3), 581-572. http://dx.doi.org/10.1080/0042098032000053932

Lavers, T. (2008). Reconciling the needs and wants of respondents in two rural Ethiopian communities. Social Indicator Research, 86, 129-147. http://dx.doi.org/10.1007/s11205-007-9110-x

Lyndon, N., Er, A.C, Selvadurai, S., Fuad, M. J., Junaidi, A. B., \& Rosniza, A. C. R. (2012). Construct of economic participation of rural native men and women. Journal of Applied Sciences Research, 8(8), 4103-4112.

Madeline, B. (2004). Towards the National Vision Policy: Review of the Economic Policy and New Development Policy among the Bumiputera Communities in Sarawak. Journal of Malaysian Studies, 21(1-2), 211-256.

McGregor, J. A., Camfield, L., \& Woodcock, A. (2009). Needs, wants and goals: wellbeing, quality of life and public policy. Applied Research in Quality of Life, 4(2), 135-154. http://dx.doi.org/10.1007/s11482-009-9069-7

Minichiello, V., Aroni, R., Timewell, E., \& Alexander, L. (1995). In-depth Interviewing: Principles, Techniques, Analysis (2nd ed.). Australia: Longman.

Morris, M. W., Leung, K., Ames, D., \& Lickel, B. (1999). Views from inside and outside: Integrating Emic and Etic Insights about Culture and Justice Judgment. The Academy of Management Review, 24(4), 781-796.

Ngidang, D., \& Abdul, R. A. (1999). Rural Cooperative Societies and Community Development in Sarawak. In V. T. King (Ed.), Rural Development and Social Science Research: Case Studies from Borneo (pp. 251-267). Borneo Research Council.

Novel, L., Sivapalan, S., Er, A. C., Mohd Fuad, M. J., Zaidah, M., Aisah, M., \& Buang, A. (2011). Intangible factors influencing gender difference in educational attainment using an abductive research strategy. World Applied Science Journal, 13, 46-52.

Ong, P. L. (2007). Pedagogi pembangunan ke arah dialog bermakna antara penggubal dasar dan sasaran pembangunan. Kertas kerja yang dibentangkan dalam Persidangan Antarabangsa, Fakulti Sains Sosial dan Kemanusiaan Kedua (ICOSH 07), anjuran Fakulti Sains Sosial dan Kemanusiaan, UKM Bangi, pada 13-15 Mac 2007.

Robertson, A. J. (1984). People and the state. An anhtropology of planned development. Cambridge University Press, Cambridge. http://dx.doi.org/10.1017/CBO9780511558122

Sanjaya, A., Etsuo, Y., Masamine, J., \& Susumu, W. (2005). Empowering rural women through a community development approach in Nepal. Community Development Journal, 42, 34-46. http://dx.doi.org/10.1093/cdj/bsi064

Sarawak. (2010). Population and housing census of Malaysia. Department of Statistics. Kuala Lumpur: Gov't Printing Office.

Sarawak. (2011). Rangkaian Khidmat Awam Negeri Sarawak, Januari-Disember, 2011. A monthly Publication of the Sarawak State Secretary's Office.

Schutz, A. (1976). The Phenomenology of the Social World. London: Heinemann.

Sen, A. (1999). Development as freedom. Oxford, UK: Oxford University Press.

Shamsul, A. B. (1977). Rancangan Malaysia Kedua: Satu Penilaian dan kritikan teoritis. Akademika, Bil.10.

Sharina, A. H., \& Hood, S. (2007). Perspectives on gender participation on Langkawi Island development. Kertas kerja dibentangkan di Post MSC5 Workshop Capacity Building for young scholars. Anjuran Persatuan Sains Sosial Malaysia, Institut Kajian Malaysia dan Antarabangsa (IKHMAS), Universiti Kebangsaan Malaysia, 22 Januari 2007.

Songan, P. (1993). Obstacles to participation in rural development: A case study of a land development project in Sarawak, Malaysia. Adult Education and Development Journal, 41, 163-181. 
Taylor, S. T., \& Bogdan, R. (1998). Introduction to Qualitative Research Methods: A Guidebook and Resource. New York: John Wiley and Sons, Inc.

Thorbecke, E. (2004). Conceptual and measurement issues in poverty analysis, WIDER Discussion Papers. World Institute for Development Economics (UNUWIDER). Retrieved from http://hdl.handle.net/10419/52879

Tosun, C. (2000). Limits to community participation in the tourism development process in developing countries. Tourism Management, 21(6), 613-633. http://dx.doi.org/10.1016/S0261-5177(00)00009-1

Van Wicklin, W. A. (2001). The World Bank's experience with local participation and partnerships: Lessons from and OED evaluation (atas talian). Retrieved January 9, 2003, from http://www.undp.org/csopp/CSO/New Files/docemppeople1.html

Wan Zawawi, I. (1998). Orang Asli Identity in the Nation-State. Journal of Malaysian and Comparative Law, 28, $1-15$.

Wandersman, A. (1981). A framework of participation in community organization. Journal of Applied Behavioural Science, 17(1), 27-58. http://dx.doi.org/10.1177/002188638101700103

$\mathrm{Xu}, \mathrm{W} .$, \& Chow, J. C. (2006). Urban community in China: service, participation and development. International Journal of Social Welfare, 15, 199-208. http://dx.doi.org/10.1111/j.1468-2397.2006.00419.x

Yapa, L. (1996). What causes poverty? A postmodern view. Annals of the Association of American Geographers, 86(4), 707-728. http://dx.doi.org/10.1111/j.1467-8306.1996.tb01773.x

Zakus, J. D. L., \& Lysack, C. L. (1998). Revisiting community participation. Health Policy and planning, 13(1), 1-12. Retrieved from http://heapol.oxfordjournals.org/content/13/1/1.full.pdf http://dx.doi.org/10.1093/heapol/13.1.1 